\title{
一般口演 14
}

\author{
近赤外線を用いた舌脂肪の評価 \\ Evaluation of Tongue Fat via Near Infrared Interactance \\ ○重田優子, 安藤栄里子, 井川知子, 木原环也, 伊藤崇弘, 重本修伺, 小川 匠 \\ Shigeta Y, Ando E, Ikawa T, Kihara T, Ito T, Shigemoto S, Ogawa T \\ 鶴見大学歯学部クラウンブリッジ補経学講座 \\ Department of Fixed Prosthodontics, Tsurumi University School of Dental Medicine
}

\begin{abstract}
I. 目的
閉塞性無呼吸症候群（OSA）の主な発症原因として, 肥満や顎骨形態などが挙げられる。我々は，X線画像 データから, OSA 患者の舌/下顎骨体積比と上気道の 形態を評価し, BMI の増加に伴う舌/下顎骨比の増加 は，気道容量の減少と関連していることを報告した ${ }^{1)}$. しかし, 肥満に伴う舌の組成変化の把握は困難であっ た. 本研究では, 近赤外線を用いて舌脂肪を評価し, OSA 患者の舌脂肪蓄積の特徵と, OSA 発症/重症度と の関連を検討することとした。
\end{abstract}

\section{II. 方 法}

\section{1. 被験者}

2014年 4 月〜 12 月の間に, 睡眠時無呼吸症候群の症 状,または，いびきを主訴に，鶴見大学歯学部附属病院 補綴科を受診し PSG 検査を受けた 45 名（男性 34 名, 女 性11名, $61 \pm 12.1$ 歳）をOSA 群とした。対照群は，い びきや日中の傾眠など, 睡眠時無呼吸症候群の自覚症状 のないボランティア 28 名（男性17名, 女性11名, $41 \pm$ 11.2 歳）とした。

\section{2. 体組成測定}

体組成の測定に生体インピーダンス方式（BI 方式） 体組成計（Karada Scan, OMURON, Kyoto, Japan）と 近赤外線方式体脂肪計 (FITNESS ANALYZER BFT3000, Kett Electric Laboratory, Tokyo, Japan)を用いた。 測定項目は, BI 方式では(1) BMI $\left(\mathrm{kg} / \mathrm{m}^{2}\right)$, (2)体脂肪率 (\%), (3)内臟脂肪率 (\%), (4)皮下脂肪率 (\%), とし
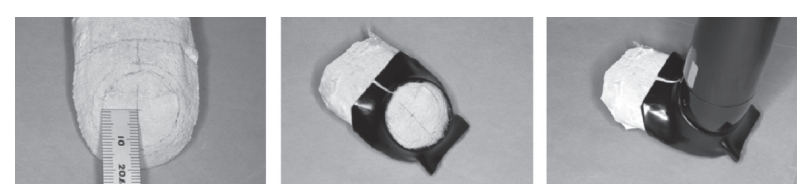

図 1 舌計測用ジグ

た。近赤外線方式では(1) Arm fat NIR（\%)(体脂肪率) と (2) Tongue fat NIR（\%）(舌脂肪率）とし，体脂肪率 は, メーカー指示に従い上腕二頭笳部で計測した。舌脂 肪は，熱収縮チューブを用いて測定ジグを作製し，舌尖 から $20 \mathrm{~mm}$ の舌背部を計測中心とした（図 1 ）.

\section{3. 統計解析}

統計解析には, SPSS 12.0J (SPSS Japan Inc. Tokyo, Japan）を用い，有意水準 $5 \%$ で検定を行った。各パラ メータの正規性については, Kolmogorov-Smirnovを用 いた。正規性の得られたパラメータは Spearman's test, 得られなかったパラメータは Pearson's testを用いて相 関を検討し，群間比較には t-testを用いた。

\section{III. 結果及び考察}

\section{1. 体組成}

OSA 群の BMI は, $26.3 \pm 4.15 \mathrm{~kg} / \mathrm{m}^{2}$ であった. PSG の検査結果に扔いて, AHI は $37.4 \pm 20.32$ events/hour であった．対照群の BMIは, $23.9 \pm 3.57 \mathrm{~kg} / \mathrm{m}^{2}$ であっ た. 男性の OSA 群と対照群, 女性の OSA 群と対照群 の BMI に有意差は認められなかった。男性群の BMI が 女性に比較し高かったにもかかわらず，体脂肪率と皮下 


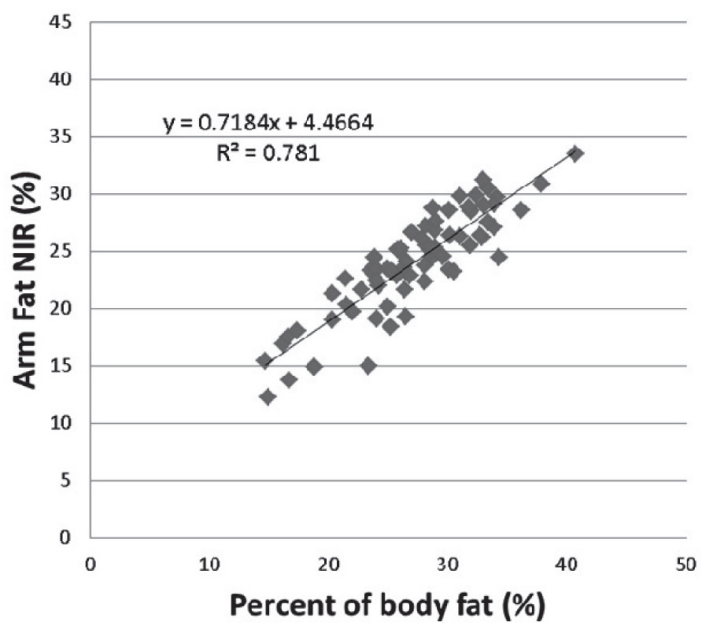

図 2 体脂肪率と Arm fat NIR の関係

脂肪率は, 女性群で有意に高かった（ $\mathrm{p}<.001 ）$. 一方， 内臓脂肪率は，男性で有意に高かった $(\mathrm{p}<.001)$.

\section{BI 方式と近赤外線方式}

全被験者に扔いて，BI 方式で計測した体脂肪率と近 赤外線方式の Arm fat NIR の間に高い相関が認められ た $(\mathrm{r}=.884, \mathrm{p}<.001)$ (図 2$)$. 近赤外線方式では, 電気 抵抗を利用しないことから, 湿潤下の計測にも対応可能 との報告 ${ }^{2}$ がある. 以上のことから, 近赤外線方式体脂 肪計は舌脂肪の計測が可能であると考えられる.

\section{3. 舌脂肪率 (Tongue fat NIR)}

OSA 群の舌脂肪率は, $17.4 \pm 3.75 \%$, 対照群は, 16.0 土3.68\%であった。この結果は, MRIを用いた先行研 究 ${ }^{3)}$ の結果に近似する, 全被験者, 女性に打いて, 舌脂 肪率は対照群とOSA 群間に有意な差は認められなかっ た ( $\mathrm{p}=.127, \mathrm{p}=.091)$. 男性では, 舌脂肪率は対照群と 比較し OSA 群で有意に大きかった $(\mathrm{p}=.027)$.

\section{4. 舌脂肪率と年齢との関係}

全被検者, 対照群, OSA 群に扔いて舌脂肪率と年齢 の間に有意な相関は認められなかった。男性では舌脂肪 率と年齢の間に有意な正の相関が認められた $(\mathrm{r}=.372$, $\mathrm{p}=.007)$. 女性では有意な相関は認められなかった。舌

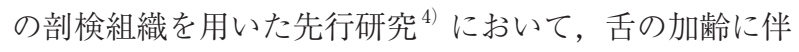
う萎縮は, 進行性脂肪変性によって特徵づけられると報 告されており, 本研究においては, 男性において, その
傾向が強く認められた.

\section{5. 体脂肪率と舌脂肪率との関係}

全被検者, 対照群, OSA 群の体脂肪率と舌脂肪率の 間に有意な正の相関が認められた（全被験者 $: r=.626$, $\mathrm{p}<.001$, 対照群: $\mathrm{r}=.607, \mathrm{p}=.001$, OSA 群 $: \mathrm{r}=.639$, $\mathrm{p}<.001)$.

\section{6. 舌脂肪率と OSA 重症度 (AHI) との関係}

OSA 群抒よび男性 OSA 群に抒いて, 舌脂肪率と $\mathrm{AHI}$ の間に有意な相関は認められなかった。女性 OSA 群では, 舌脂肪率と $\mathrm{AHI}$ の間に有意な正の相関が認め られた $(\mathrm{r}=.763, \mathrm{p}=.006)$.

二重エネルギー $\mathrm{X}$ 線吸光光度法による口腔周囲組織 組成測定值の結果から, OSA 患者に扮ける除脂肪体 重が, 対照群と比較し有意に少なかったとの報告があ る5)。また，オトガイ舌筋活性は閉経後女性で低下し， この外舌筋の機能低下は, 脂肪化を誘発するとの報告 ${ }^{6}$ もある。これらの過去の報告と今回の結果は, 舌脂肪と OSA 発現との関連を示唆している.

\section{N. 文献}

1 ) Shigeta Y, Ogawa T, Ando E, et al. Influence of tongue/mandible volume ratio on oropharyngeal airway in Japanese male patients with obstructive sleep apnea. Oral Surg Oral Med Oral Pathol Oral Radiol Endod. 2011; 111: 239-243.

2 ) 勝野久美子, 福山由美子, 西山久美子ほか. 近赤 外線法による体脂肪計の測定条件に関する基礎的 検討. 長崎大学医療技術短期大学部紀要 $1991 ; 5$ ： 23-32.

3 ) Kim AM, Keenan BT, Jackson N, et al. Tongue fat its relationship to obstructive sleep apnea Sleep. 2014; 37: 1639-48.

4 ) Bässler R. Histopathology of different types of atrophy of the human tongue. Pathol Res Pract. 1987; 182: 87-97.

5 ) Bruno E, Alessandrini M, Napolitano B, et al. Dualenergy X-ray absorptiometry analysis of body composition in patients affected by OSAS. Eur Arch Otorhinolaryngol. 2009; 266: 1285-1290.

6 ) Popovic RM, White DP. Upper airway muscle activity in normal women: influence of hormonal status. J Appl Physiol. 1998; 84: 1055-1062. 